\title{
Going beyond The three worlds of welfare capitalism: regime theory and public health research
}

\section{Bambra}

J Epidemiol Community Health 2007;61:1098-1102. doi: 10.1136/jech.2007.064295

Correspondence to:

C Bambra, Centre for Public Policy and Health, Wolfson Research Institute, Durham University, Queen's Campus, Stockton-on-Tees TS17 6BH, UK; clare. bambra@durham.ac.uk

Accepted 15 June 2007

\begin{abstract}
International research on the social determinants of health has increasingly started to integrate a welfare state regimes perspective. Although this is to be welcomed, to date there has been an over-reliance on EspingAndersen's The three worlds of welfare capitalism typology (1990). This is despite the fact that it has been subjected to extensive criticism and that there are in fact a number of competing welfare state typologies within the comparative social policy literature. The purpose of this paper is to provide public health researchers with an up-to-date overview of the welfare state regime literature so that it can be reflected more accurately in future research. It outlines The three worlds of welfare capitalism typology, and it presents the criticisms it received and an overview of alternative welfare state typologies. It concludes by suggesting new avenues of study in public health that could be explored by drawing upon this broader welfare state regimes literature.
\end{abstract}

l nternational research on the social determinants of health and health inequalities has increasingly begun to draw upon the comparative social policy literature. Specifically, research has concentrated on examining, and to some extent explaining, differences in health outcomes between and within developed countries by comparing different types of welfare state regimes and their respective politics and policies. ${ }^{1-10}$ Recent calls for further analysis of the political nature of health (and indeed the creation of "political epidemiology") suggest that it is likely that such research will grow in the future. ${ }^{11}{ }^{12}$ However, public health research has to date relied extensively on the typology of welfare state regimes proposed by Esping-Andersen in his 1990 publication (which used 1980 data), The three worlds of welfare capitalism. ${ }^{13}$ This is despite the fact that within the discipline of social policy, Esping-Andersen's typology has long been the subject of extensive scholarly criticism and there is in fact a number of competing welfare state typologies that may also be of use in public health research. ${ }^{14-22}$ The purpose of this paper is to provide public health researchers and epidemiologists with an up-to-date overview of the social policy literature on welfare state regimes, so that our research can reflect and benefit from the more contemporaneous insights on offer from the "welfare modelling business" ${ }^{20}{ }^{21}$

This paper begins by summarising Esping-Andersen's seminal work, The three worlds of welfare capitalism; it then presents the various criticisms that this theory received and outlines the resulting alternative welfare state typologies that emerged. It concludes by suggesting new avenues of study in public health that could be explored by drawing upon this broader welfare state regimes literature. Although there are existing reviews of welfare state regime theory, these are somewhat outdated and, perhaps more importantly, they were not written specifically for or publicised to a public health audience. ${ }^{20} 21$

\section{THE THREE WORLDS OF WELFARE}

In The three worlds of welfare capitalism (1990), ${ }^{13}$ Esping-Andersen presents a typology of 18 Organisation of Economic Cooperation and Development (OECD) welfare states based upon three principles: decommodification (the extent to which an individual's welfare is reliant upon the market, particularly in terms of pensions, unemployment benefit and sickness insurance), social stratification (the role of welfare states in maintaining or breaking down social stratification) and the private-public mix (the relative roles of the state, the family, the voluntary sector and the market in welfare provision). The operationalisation of these principles, largely using decommodification indexes, leads to the division of welfare states into three ideal regime types (Esping-Andersen; Table 1): Liberal, Conservative and Social Democratic. ${ }^{13}$

In the Liberal regime countries, state provision of welfare is minimal, benefits are modest and often attract strict entitlement criteria, and recipients are usually means-tested and stigmatised. The Conservative welfare state regime is distinguished by its "status differentiating" welfare programmes in which benefits are often earnings-related, administered through the employer and geared towards maintaining existing social patterns. The role of the family is also emphasised and the redistributive impact is minimal. The Social Democratic regime is the smallest regime cluster. Welfare provision is characterised by universal and comparatively generous benefits, a commitment to full employment and income protection, and a strongly interventionist state used to promote equality through a redistributive social security system. ${ }^{13}$

\section{GOING BEYOND THE THREE WORLDS OF WELFARE CAPITALISM}

The three worlds of welfare capitalism typology has sparked a volatile and ongoing debate and, indeed, much of the burgeoning comparative social policy literature since 1990 can be seen as a "settling of accounts" with Esping-Andersen. ${ }^{21}{ }^{23}$ This process has led to the development of alternative typologies, many of which are intended to reflect aspects that were not examined in Esping-Andersen's original typology, that extend the range of countries included in the analysis, and that take more account of gender, politics or the role of public services. ${ }^{416-19}$ 22-37 The criticism has been on three fronts: theoretical, methodological and empirical.

Abbreviation: $\mathrm{OECD}$, Organisation of Economic Cooperation and Development 
Table 1 Welfare state typologies ${ }^{15}$

\begin{tabular}{|c|c|c|c|c|c|c|}
\hline Author & Measures & Welfare state regimes & & & & \\
\hline $\begin{array}{l}\text { Esping-Andersen } \\
(1990)^{13}\end{array}$ & $\begin{array}{l}18 \text { countries } \\
\text { - Decommodification } \\
\text { - Social stratification } \\
\text { - Private-public mix }\end{array}$ & $\begin{array}{l}\text { Liberal } \\
\text { Australia } \\
\text { Canada } \\
\text { Ireland } \\
\text { New Zealand } \\
\text { UK } \\
\text { USA }\end{array}$ & $\begin{array}{l}\text { Conservative } \\
\text { Finland } \\
\text { France } \\
\text { Germany } \\
\text { Japan } \\
\text { Italy } \\
\text { Switzerland }\end{array}$ & $\begin{array}{l}\text { Social Democratic } \\
\text { Austria } \\
\text { Belgium } \\
\text { The Netherlands } \\
\text { Denmark } \\
\text { Norway } \\
\text { Sweden }\end{array}$ & & \\
\hline Leibfried $(1992)^{19}$ & $\begin{array}{l}15 \text { countries } \\
\text { - Characteristics } \\
\text { - Rights } \\
\text { - Basic income }\end{array}$ & $\begin{array}{l}\text { Anglo-Saxon } \\
\text { Australia } \\
\text { New Zealand } \\
\text { UK } \\
\text { USA }\end{array}$ & $\begin{array}{l}\text { Bismarck } \\
\text { Austria } \\
\text { Germany }\end{array}$ & $\begin{array}{l}\text { Scandinavian } \\
\text { Denmark } \\
\text { Finland } \\
\text { Norway } \\
\text { Sweden }\end{array}$ & $\begin{array}{l}\text { Latin rim } \\
\text { France } \\
\text { Greece } \\
\text { Italy } \\
\text { Portugal } \\
\text { Spain }\end{array}$ & \\
\hline $\begin{array}{l}\text { Castles and Mitchell } \\
(1993)^{22}\end{array}$ & $\begin{array}{l}14 \text { countries } \\
\text { - Aggregate welfare expenditure } \\
\text { - Benefit equality }\end{array}$ & $\begin{array}{l}\text { Liberal } \\
\text { Ireland } \\
\text { Japan } \\
\text { Switzerland } \\
\text { USA }\end{array}$ & $\begin{array}{l}\text { Conservative } \\
\text { Germany } \\
\text { Italy } \\
\text { The Netherlands }\end{array}$ & $\begin{array}{l}\text { Non-right hegemony } \\
\text { Belgium } \\
\text { Denmark } \\
\text { Norway } \\
\text { Sweden }\end{array}$ & & $\begin{array}{l}\text { Radical } \\
\text { Australia } \\
\text { New Zealand } \\
\text { UK }\end{array}$ \\
\hline Kangas $(1994)^{39}$ & $\begin{array}{l}15 \text { countries } \\
\cdot \text { Cluster analysis of } \\
\text { decommodification }\end{array}$ & $\begin{array}{l}\text { Liberal } \\
\text { Canada } \\
\text { USA }\end{array}$ & $\begin{array}{l}\text { Conservative } \\
\text { Austria } \\
\text { Germany } \\
\text { Italy } \\
\text { Japan } \\
\text { The Netherlands }\end{array}$ & $\begin{array}{l}\text { Social democratic } \\
\text { Denmark } \\
\text { Finland } \\
\text { Norway } \\
\text { Sweden }\end{array}$ & & $\begin{array}{l}\text { Radical } \\
\text { Australia } \\
\text { Ireland } \\
\text { New Zealand } \\
\text { UK }\end{array}$ \\
\hline Ragin $(1994)^{40}$ & $\begin{array}{l}18 \text { countries } \\
\cdot \text { BOOLEAN comparative } \\
\text { analysis of pensions } \\
\text { decommodification }\end{array}$ & $\begin{array}{l}\text { Liberal } \\
\text { Australia } \\
\text { Canada } \\
\text { Switzerland } \\
\text { USA }\end{array}$ & $\begin{array}{l}\text { Corporatist } \\
\text { Austria } \\
\text { Belgium } \\
\text { Finland } \\
\text { France } \\
\text { Italy }\end{array}$ & $\begin{array}{l}\text { Social democratic } \\
\text { Denmark } \\
\text { Sweden } \\
\text { Norway }\end{array}$ & $\begin{array}{l}\text { Undefined } \\
\text { Germany } \\
\text { Ireland } \\
\text { Japan } \\
\text { The Netherlands } \\
\text { New Zealand } \\
\text { UK }\end{array}$ & \\
\hline Ferrera $(1996)^{18}$ & $\begin{array}{l}15 \text { countries } \\
\text { - Coverage } \\
\text { - Replacement rates } \\
\text { - Poverty rates }\end{array}$ & $\begin{array}{l}\text { Anglo-Saxon } \\
\text { Ireland } \\
\text { UK }\end{array}$ & $\begin{array}{l}\text { Bismarck } \\
\text { Austria } \\
\text { Belgium } \\
\text { France } \\
\text { Germany } \\
\text { Luxembourg } \\
\text { The Netherlands } \\
\text { Switzerland }\end{array}$ & $\begin{array}{l}\text { Scandinavian } \\
\text { Denmark } \\
\text { Finland } \\
\text { Norway } \\
\text { Sweden }\end{array}$ & $\begin{array}{l}\text { Southern } \\
\text { Greece } \\
\text { Italy } \\
\text { Portugal } \\
\text { Spain }\end{array}$ & \\
\hline Bonoli (1997) ${ }^{17}$ & $\begin{array}{l}16 \text { countries } \\
\text { - Social expenditure as \% GDP } \\
\text { - Social expenditure financed } \\
\text { via contributions }\end{array}$ & $\begin{array}{l}\text { British } \\
\text { Ireland } \\
\text { UK }\end{array}$ & $\begin{array}{l}\text { Continental } \\
\text { Belgium } \\
\text { France } \\
\text { Germany } \\
\text { Luxembourg } \\
\text { The Netherlands }\end{array}$ & $\begin{array}{l}\text { Nordic } \\
\text { Denmark } \\
\text { Finland } \\
\text { Norway } \\
\text { Sweden }\end{array}$ & $\begin{array}{l}\text { Southern } \\
\text { Greece } \\
\text { Italy } \\
\text { Portugal } \\
\text { Spain } \\
\text { Switzerland }\end{array}$ & \\
\hline $\begin{array}{l}\text { Korpi and Palme } \\
(1998)^{32}\end{array}$ & $\begin{array}{l}18 \text { countries } \\
\text { - Social expenditure as \% GDP } \\
\text { - Luxembourg income study } \\
\text { - Institutional characteristics }\end{array}$ & $\begin{array}{l}\text { Basic security } \\
\text { Canada } \\
\text { Denmark } \\
\text { Ireland } \\
\text { The Netherlands } \\
\text { New Zealand } \\
\text { Switzerland } \\
\text { UK } \\
\text { USA }\end{array}$ & $\begin{array}{l}\text { Corporatist } \\
\text { Austria } \\
\text { Belgium } \\
\text { France } \\
\text { Germany } \\
\text { Italy } \\
\text { Japan }\end{array}$ & $\begin{array}{l}\text { Encompassing } \\
\text { Finland } \\
\text { Norway } \\
\text { Sweden }\end{array}$ & & $\begin{array}{l}\text { Targeted } \\
\text { Australia }\end{array}$ \\
\hline Pitzurello $(1999)^{41}$ & $\begin{array}{l}18 \text { countries } \\
\text { - Cluster analysis } \\
\text { of decommodification }\end{array}$ & $\begin{array}{l}\text { Liberal } \\
\text { Canada } \\
\text { Ireland } \\
\text { UK } \\
\text { USA }\end{array}$ & $\begin{array}{l}\text { Conservative } \\
\text { Germany } \\
\text { The Netherlands } \\
\text { Switzerland }\end{array}$ & $\begin{array}{l}\text { Social Democratic } \\
\text { Belgium } \\
\text { Denmark } \\
\text { Norway } \\
\text { Sweden }\end{array}$ & $\begin{array}{l}\text { Conservative- } \\
\text { Bismarckian } \\
\text { Austria } \\
\text { Finland } \\
\text { France } \\
\text { Italy } \\
\text { Japan }\end{array}$ & $\begin{array}{l}\text { Radical } \\
\text { Australia } \\
\text { New Zealand }\end{array}$ \\
\hline $\begin{array}{l}\text { Navarro and Shi } \\
(2001)^{4}\end{array}$ & $\begin{array}{l}18 \text { countries } \\
\text { - Political tradition }\end{array}$ & $\begin{array}{l}\text { Liberal-Anglo Saxon } \\
\text { Canada } \\
\text { Ireland } \\
\text { UK } \\
\text { USA }\end{array}$ & $\begin{array}{l}\text { Christian Democrat } \\
\text { Belgium } \\
\text { The Netherlands } \\
\text { Germany } \\
\text { France } \\
\text { Italy } \\
\text { Switzerland }\end{array}$ & $\begin{array}{l}\text { Social Democratic } \\
\text { Sweden } \\
\text { Norway } \\
\text { Denmark } \\
\text { Finland } \\
\text { Austria }\end{array}$ & $\begin{array}{l}\text { Ex-fascist } \\
\text { Spain } \\
\text { Greece } \\
\text { Portugal }\end{array}$ & \\
\hline Kautto $(2002)^{30}$ & $\begin{array}{l}15 \text { countries } \\
\text { - Expenditure on services and } \\
\text { social transfers }\end{array}$ & & $\begin{array}{l}\text { Transfer approach } \\
\text { Belgium } \\
\text { The Netherlands } \\
\text { Austria } \\
\text { Italy }\end{array}$ & $\begin{array}{l}\text { Service approach } \\
\text { Sweden } \\
\text { Norway } \\
\text { Finland } \\
\text { Germany } \\
\text { UK }\end{array}$ & $\begin{array}{l}\text { Low approach } \\
\text { Ireland } \\
\text { Greece } \\
\text { Portugal } \\
\text { Spain }\end{array}$ & \\
\hline Bambra $(2005)^{26} 27$ & $\begin{array}{l}18 \text { countries } \\
\text { - Healthcare services and } \\
\text { decommodification }\end{array}$ & $\begin{array}{l}\text { Liberal } \\
\text { Australia } \\
\text { Japan } \\
\text { USA }\end{array}$ & $\begin{array}{l}\text { Conservative } \\
\text { Austria } \\
\text { Belgium } \\
\text { Canada } \\
\text { Denmark } \\
\text { France } \\
\text { Italy }\end{array}$ & $\begin{array}{l}\text { Social Democratic } \\
\text { Finland } \\
\text { Norway } \\
\text { Sweden }\end{array}$ & $\begin{array}{l}\text { Conservative subg } \\
\text { Germany } \\
\text { Switzerland } \\
\text { The Netherlands }\end{array}$ & $\begin{array}{l}\text { pliberal } \\
\text { Subgroup } \\
\text { Ireland } \\
\text { UK } \\
\text { New Zealand }\end{array}$ \\
\hline
\end{tabular}




\section{Theoretical critiques}

The range of countries and regimes

The range of countries used to construct Esping-Andersen's typology has met with criticism. ${ }^{17-19}{ }^{22}$ Esping-Andersen only examined 18 OECD countries and in doing so he placed both Italy and Japan within the Conservative regime. Some commentators assert that when the Latin rim countries of the European Union (Spain, Portugal, Greece) are added into the analysis, a fourth "Southern" world of welfare emerges into which Italy can also be placed (Bonoli, Ferrera, Liebfreid; Table 1). ${ }^{17-19}$ The Southern welfare states are described as "rudimentary" because they are characterised by their fragmented system of welfare provision, which consists of diverse income maintenance schemes, ranging from the meagre to the generous, and a healthcare system that provides only limited and partial coverage. ${ }^{19}$ Reliance on the family and voluntary sector is also a prominent feature.

Furthermore, research into East Asian welfare states (South Korea, Taiwan, Hong Kong, Singapore) has suggested that these countries, including Japan, form a further Confucian welfare state regime. ${ }^{24} 28$ The Confucian welfare state is characterised by low levels of government intervention and investment in social welfare, underdeveloped public service provision, and the fundamental importance of the family and voluntary sector in providing social safety nets. This minimalist approach is combined with Confucian social ethics (obligation for immediate family members, thrift, diligence, and a strong education and work ethic). ${ }^{37}$ Overall, the Confucian welfare state regime could be considered as combining some elements of the Liberal, Conservative and Southern regimes.

In addition, Castles and Mitchell (1993) cross-classified the same 18 OECD nations used by Esping-Andersen and examined their high- and low-aggregate expenditure levels, and their high and low degrees of benefit equality. On the basis of this analysis, they argued that the UK, Australia and New Zealand constitute a Radical, targeted form of welfare state, one in which "the welfare goals of poverty amelioration and income equality are pursued through redistributive instruments rather than by high expenditure levels" (Castles and Mitchell; Table 1). ${ }^{22}$ In the same vein, Korpi and Palme describe the existence of a Targeted welfare state regime (Korpi and Palme; Table 1). ${ }^{32}$

\section{The gender-blind "worlds of welfare"}

It has been argued that the analysis behind The three worlds of welfare capitalism typology was "gender-blind" (androgynous). ${ }^{34}{ }^{35}$ Aside from the overt absence of women in EspingAndersen's analysis, the critique revolves around three other issues: the gender-blind concept of decommodification, the unawareness of the role of women and the family in the provision of welfare, and the lack of consideration given to gender as a form of social stratification. ${ }^{33-35}$ These criticisms suggest limitations to the comprehensiveness and generalisability of the Three Worlds thesis - especially in regard to any claims about women, welfare and the family.

The gender-blind critique of Esping-Andersen has led to both theoretical attempts to "gender" his analysis, and also, the construction of alternative welfare state typologies in which gender has been a more overt and centralised part of the analysis. ${ }^{1625293134-36}$ Most notable amongst these new typologies are the defamilisation approaches that examine the extent to which welfare states, and welfare state regimes, facilitate female autonomy and economic independence from the family. ${ }^{16252931}$ The difference made to the composition, and number, of welfare state regimes made by the addition of a defamilisation-based analysis, however, is contested and is rather dependent on how the concept is operationalised. ${ }^{16}$
However, to date, there has been no exploration of defamilisation and health or indeed how the relationship between gender and health varies by welfare state regime.

\section{The "illusion" of welfare state regimes}

This critique focuses on Esping-Andersen's decision to organise the principle of classification around the study of social transfers: pensions, sickness benefits and unemployment benefits. $^{20} 262730$ This ignores the fact that welfare states are also about the actual delivery of services such as healthcare, education or social services. ${ }^{30}$ It is suggested that countries vary in terms of the emphasis that they place upon welfare state services and/or social transfers. ${ }^{27}{ }^{30}$ However, Esping-Andersen's regimes concept generalises about all forms of welfare state provision on the basis of social transfers. ${ }^{38}$ This has led some to question the validity of the regimes concept itself as it assumes that most of the key social policy areas within a welfare regime will reflect a similar, across the board, approach to welfare provision; and second, that each regime type itself reflects "a set of principles or values that establishes a coherence in each country's welfare package" ${ }^{38}$

This has resulted in the production of alternative typologies based on the extent of services provided by different welfare states. $^{26}{ }^{27}{ }^{30}$ These are often substantially different in composition from The three worlds of welfare capitalism. For example, Kautto's comparison of the balance between expenditure on social transfers and welfare services in 15 European countries concluded that welfare states could indeed be divided into three regimes but these were very different in composition and emphasis from Esping-Andersen's The three worlds of welfare capitalism (Kautto; Table 1). ${ }^{30}$ Similarly, a typology based on the comparison of the decommodification of healthcare services and social transfers in 18 OECD countries led to a fivefold typology suggesting subgroups within both the Conservative and Liberal regimes (Bambra; Table 1). ${ }^{27}$

Taking the logic of this critique further still, researchers from the field of political economy have suggested that analysing "political" regimes may prove to be a more fruitful research paradigm. ${ }^{4} 7$ In addition to criticising The three worlds of welfare capitalism, ${ }^{4}{ }^{7}$ they have also highlighted the limited nature of the other alternative typologies, which, in common with EspingAndersen, focus too much on the characteristics of welfare states to the exclusion of a thorough examination of the policies and politics underpinning and supporting them. Subsequently, a more historical-political analysis led to the development of a fourfold political typology of welfare states (Navarro and Shi; Table 1) in which Greece, Spain and Portugal form an exFascist regime. ${ }^{4}$

\section{Methodological issues}

The limitations of Esping-Andersen's methodology have also been exposed. Attention has been placed particularly upon the additive nature of the decommodification indexes, weighting within the indexes, the reliance upon averaging, and the use of one standard deviation around the mean to classify the countries into regimes (which meant that only a threefold classification was possible: regime classification is either above [Social Democratic], below [Liberal] or within [Conservative] one standard deviation around the mean). ${ }^{13} 142239-41$ This method has a noticeable impact on the classification of certain countries, eg. the UK which, if a different cut-off point was used, may not have fallen within the Liberal regime. ${ }^{14} 42$ These concerns led to the utilisation of more statistically robust methodologies (most notably cluster analysis), the results of which have challenged the accuracy of the threefold typology by identifying four or five different types of welfare state (Kangas, Ragin, Pitzurello; Table 1). ${ }^{39-41}$ 


\section{Empirical validity}

Somewhat inevitably, this has led to the questioning of the ongoing empirical validity of The three worlds of welfare capitalism typology. Recently Esping-Andersen's study was replicated and the results differed substantially from the original. ${ }^{43}$ In addition, it has been found that the miscalculation of the mean and standard deviation in the original Three worlds of welfare capitalism data led to the misclassification of three borderline countries (Japan, UK and Ireland). ${ }^{10}$ Furthermore, an updated analysis of decommodification using data from 1998/9 has suggested that the relationships between the 18 OECD countries have changed significantly and that the composition of welfare state regimes is not static. ${ }^{10}$ Taken together, these pieces of research bring into question the extent to which The three worlds of welfare capitalism still exist, and indeed, at least in empirical terms, the extent to which they ever did. ${ }^{14}$

\section{PUBLIC HEALTH RESEARCH BEYOND THE THREE WORLDS OF WELFARE CAPITALISM}

In light of this overview, it seems somewhat bizarre that public health research has been near oblivious to these substantial developments in social policy research since the publication of The three worlds of welfare capitalism in 1990 and that, with the notable exception of work by the political economy school, ${ }^{2-4} 7$ epidemiological research utilises Esping-Andersen's typology in a surprisingly uncritical manner. Indeed, a recent overview of welfare states and health inequalities makes scant mention of the existence of alternative regime typologies. ${ }^{6}$ Furthermore, Esping-Andersen's typology is often used to justify the choice of case study countries and subsequent findings are implicitly applied to all other countries in that particular regime. ${ }^{1}$ Although The three worlds of welfare capitalism is clearly an acceptable starting point in terms of examining within and between welfare state differences in health, it is vital for the ongoing utility of public health research in this area that in the future it is able to more adequately reflect, and therefore benefit from, the evolution of welfare state regime theory. More awareness of the wider regimes literature and going beyond The three worlds of welfare capitalism will be a useful first stage and one to which hopefully this paper has contributed.

Looking further ahead, there needs to be more critical engagement with the concept of regimes starting with an awareness that they are in fact "ideal types". In practice, welfare provision varies extensively between countries of the same regime type..$^{38}$ For example, research has indicated that some countries are more central to a particular regime than others (eg. Sweden or the USA) and offer a more coherent approach across both social transfers and welfare services. ${ }^{27}$ Other countries' profile (and therefore regime type) can vary extensively depending on which factors are used in regime construction. One avenue for future research would therefore be to examine the competing typologies and establish which works best in terms of health outcomes and public health research. For example, cluster analysis techniques could be used to create health-based taxonomies of welfare states which could be compared with existing welfare state typologies (Table 1). ${ }^{16}$

This work would also enable more theoretical advancement in terms of how welfare state regimes are expected to impact on health and health inequalities. ${ }^{6}$ This is especially the case in terms of welfare states, gender and health where, for example, there is the opportunity to develop both theoretical and empirical accounts of how welfare state regimes may moderate the relationship between gender and health status. Indeed, concepts from the wider comparative social policy literature, such as defamilisation, could also be unpacked and operationalised in relation to health. ${ }^{1625} 2931$

\section{What is already known on this subject}

- It is well known that population health in the developed world varies within and between countries.

- More recently, within social epidemiology, it has been suggested that these international differences may in part be a result of different types of welfare state arrangement (welfare state regimes).

- This research has almost exclusively focused on EspingAndersen's 1990 publication, The three worlds of welfare capitalism.

\section{What this study adds}

- This paper outlines Esping-Andersen's influential Three Worlds welfare state typology and the important criticisms it received within the comparative social policy literature.

- It overviews a number of alternative welfare state typologies with the intention of enabling the welfare state regimes approach taken by social epidemiologists to be broadened.

- It concludes by suggesting how research on welfare state regimes and health could be developed in the future.

To date, much of the engagement by public health researchers with the regimes literature has been at the overall population level. ${ }^{1-4}$ 7-10 There has been little research examining how different population subgroups fare in different welfare state regimes (for example, women, immigrant groups, lone mothers, etc.). ${ }^{54}$ Furthermore, the political economy of health research could be progressed by comparing countries that are the most similar in terms of welfare state provision, identifying areas of difference and exploring how these may contribute to cross-national differences in health and health inequalities. These types of research would help overcome some of the more banal generalisations inherent within regime research and would perhaps provide the opportunity for better advice to policy-makers on specific interventions. Similarly, the life course approach to health inequalities could be extended to examine variation in countries from different welfare state regimes. ${ }^{45}$ Ultimately though, for this area of research to expand, there is a clear need for increased dialogue and more joint research between social policy analysts and epidemiologists.

Competing interests: None declared.

\section{REFERENCES}

1 Martikainen $\mathbf{P}$, Lahelma $E$, Marmot $M$, et al. A comparison of socioeconomic differences in physical functioning and perceived health among male and female employees in Britain, Finland and Japan. Soc Sci Med 2004;59:1287-95.

2 Navarro V, Borrell C, Benach J, et al. The importance of the political and the social in explaining mortality differentials among the countries of the OECD, 1950-1998. Intl J Health Serv 2003;33:419-94.

3 Navarro V, Muntaner C, Borrell C, et al. Politics and health outcomes. Lancet 2006;368:1033-7.

4 Navarro V, Shi L. The political context of social inequalities and health. Intl J Health Serv 2001;31:1-21.

5 Raphael D, Bryant T. The welfare state as a determinant of women's health: support for women's quality of life in Canada and four comparison nations. Health Policy 2004;68:63-79.

6 Dahl E, Fritzell J, Lahelma E, et al. Welfare state regimes and health inequalities. In: Siegrist J, Marmot M, eds. Social inequalities in health. Oxford: Oxford University Press, 2006:193-222. 
7 Chung $\mathbf{H}$, Muntaner $\mathrm{C}$. Welfare state matters: a typological multilevel analysis of wealthy countries. Health Policy 2007;80:328-39.

8 Coburn D. Beyond the income inequality hypothesis: class, neo-liberalism, and health inequalities. Soc Sci Med 2004;58:41-56.

9 Conley D, Springer K. Welfare state and infant mortality. Am J Sociol $2001 ; 107: 768-807$.

10 Bambra C. Health status and the worlds of welfare. Soc Policy Society 2006;5:53-62.

11 Clarke A, McCarthy M, Alavarez-Dardet C, et al. New directions in European public health research: report of a workshop. J Epidemiol Community Health 2007;61:194-7.

12 Bambra C, Fox D, Scott-Samuel A. Towards a politics of health. Health Promot Int 2005;20:187-93.

13 Esping-Andersen G. The three worlds of welfare capitalism. London: Polity, 1990.

14 Bambra C. Decommodification and the worlds of welfare revisited. J Eur Soc Policy 2006; 16:73-80.

15 Bambra C. Sifting the wheat from the chaff: a two-dimensional discriminant analysis of welfare state regime theory. Soc Policy Adm 2007;41:1-28.

16 Bambra C. Defamilisation and welfare state regimes: a cluster analysis. Int J Soc Welfare. Published Online First: 26 February 2007. doi: 10.1111/j.14682397.2007.00486.x.

17 Bonoli J. Classifying welfare states: a two-dimension approach. J Soc Policy 1997;26:351-372.

18 Ferrera M. The southern model of welfare in social Europe. J Eur Soc Policy 1996;6:17-37.

19 Leibfreid S. Towards a European welfare state. In: Ferge Z, Kolberg JE, eds. Social policy in a changing Europe. Frankfurt: Campus-Verlag, 1992:245-79.

20 Abrahamson P. The welfare modelling business. Soc Policy Adm 1999;33:394-415.

21 Arts W, Gelissen J. Three worlds of welfare or more? J Eur Soc Policy 2002;12:137-58.

22 Castles F, Mitchell D. Worlds of welfare and families of nations. In: Castles F, ed. Families of nations: patterns of public policy in western democracies. Aldershot: Dartmouth, 1993:93-128.

23 Pierson C. Beyond the Welfare State. London: Polity, 1998.

24 Aspalter C. The East Asian welfare model. Int J Soc Welfare 2006;15:290-301.

25 Bambra C. The worlds of welfare: illusory and gender blind? Soc Policy Society 2004;3:201-12.

26 Bambra C. Worlds of welfare and the health care discrepancy. Soc Policy Society 2005;4:31-41.
27 Bambra C. Cash versus services: 'worlds of welfare' and the decommodification of cash benefits and health care services. J Soc Policy 2005;34:195-213.

28 Croissant A. Changing welfare regimes in east and southeast Asia: crisis, change and challenge. Soc Policy Adm 2004;38:504-524.

29 Esping-Andersen G. Social foundations of post-industrial economies. Oxford: Oxford University Press, 1999.

30 Kautto M. Investing in services in West European welfare states. J Eur Soc Policy 2002; 12:53-65.

31 Korpi W. Faces of inequality: gender, class and patterns of inequalities in different types of welfare states. Soc Polit 2000;7:127-91.

32 Korpi W, Palme J. The paradox of redistribution and the strategy of equality: welfare state institutions, inequality and poverty in the Western countries. Am Sociol Rev 1998;63:662-87.

33 Lewis J. Gender and the development of welfare regimes. J Eur Soc Policy 1992;2:195-211

34 Sainsbury D. Gendering welfare states. London: Sage Publications, 1994

35 Sainsbury D. Gender, policy regimes and politics. In: Sainsbury D, ed. Gender and welfare state regimes. Oxford: Oxford University Press, 1999:000-000.

36 Siaroff A. Work, welfare and gender equality: a new typology. In: Sainsbury D, ed. Gendering welfare states. London: Sage Publications, 1994:245-76.

37 Walker A, Wong C. East Asian welfare regimes in transition: from Confucianism to globalisation. Bristol: Policy Press, 2005.

38 Kasza G. The illusion of welfare regimes. J Soc Policy 2002;31:271-87.

39 Kangas $\mathrm{O}$. The politics of social security: on regressions, qualitative comparisons and cluster analysis. In: Janoski T, Hicks A, eds. The comparative political economy of the welfare state. Cambridge: Cambridge University Press, 1994:346-65.

40 Ragin C. A qualitative comparative analysis of pension systems. In: Janoski T, Hicks A, eds. The comparative political economy of the welfare state. Cambridge: Cambridge University Press, 1994:320-45.

41 Pitruzello S. Decommodification and the Worlds of Welfare Capitalism: a cluster analysis. Florence: European University Institute, 1999.

42 Fawcett H, Papadopoulos T. Social exclusion, social citizenship and decommodification: an evaluation of the adequacy of support for the unemployed in the European Union. West Eur Polit 1997;20:1-30.

43 Scruggs $\mathrm{L}$, Allan J. Welfare state decommodification in eighteen OECD countries: a replication and revision. J Eur Soc Policy 2006;16:55-72.

44 Whitehead M, Burström B, Diderichsen F. Social policies and the pathways to inequalities in health: a comparative analysis of lone mothers in Britain and Sweden. Soc Sci Med 2000;50:255-270.

45 Bartley M. Blane D. Socioeconomic determinants of health: health and the life course: why safety nets matter. BMJ 1997;314:1194-6. 